\title{
Çocuk gelişiminin dünü, bugünü ve yarını
}

\section{The past, present, and future of child development}

\author{
Makale Geçmişi \\ Geliş : 16 Nisan 2020 \\ Düzeltme : 18 Temmuz 2020 \\ Kabul : 20 Ağustos 2020
}

\section{Makale Türü}

Derleme Makale

\section{Article History}

Received : 16 April 2020

Revised : 18 July 2020

Accepted : 20 August 2020

\section{Article Type}

Review Article

\author{
Ayten Doğan-Keskin ${ }^{1}$, Nur Pınar Bayhan ${ }^{2}$
}

Öz: Çocuğun ögesi olduğu çalışmalar birçok disiplinin ilgi alanına girmektedir. Türkiye’de çocukların gelişimleriyle ilgilenen bilim dalı ise çocuk gelişimidir. Çocuk gelişiminin geçmişten günümüze yaşadı̆̆ değişim sürecini incelemek bu çalışmanın başlıca amacını oluşturmaktadır. Türkiye'de lisans düzeyinde ilk Çocuk Gelişimi bölümü 1968 yilında Hacettepe Üniversitesi’nde kurulmuştur. 2020 y1lında Türkiye'de lisans düzeyinde 86 Çocuk Gelişimi bölümü bulunmaktadır. 2019 yılı tercih kılavuzuna göre lisans düzeyinde çocuk gelişimi bölümlerinde toplam 4019 kontenjan bulunmaktadır. Türkiye'de bulunan Çocuk Gelişimi bölümlerinde toplam 255 akademik personel bulunmaktadır. 2003-2018 yılları arasında Çocuk Gelişimi mezun sayısı 6468'dir. Çocuk Gelişimciler sağlık, eğitim, sosyal hizmet, adalet ve diğer alanlarda görev yapmaktadır. Çocuk gelişimi bölümü 52 yıllık geçmişi, binlerce mezunuyla milyonlarca çocuğa hizmet etmektedir. Çocuk gelişimi bölümlerinin sayısının artmasıla \%28’i çocuk nüfusuna sahip olan Türkiye'deki tüm çocuklara ulaşmak hedeflenmektedir. Bu hedefte birincil amaç çocukların sağlı̆̆ının korunması ve geliştirilmesidir. Çocukların sağlı̆̆ının korunması ve geliştirilmesi için de daha fazla çocuk gelişimciye istihdam alanı oluşturulması büyük önem taşımaktadır.

Anahtar Kelimeler: Çocuk gelişimi, Çocuk sağlı̆̆1, Eğitim.

Abstract: Studies concerning children are conducted in many disciplines. In Turkey, universities operate child development departments that focus specifically on this field of study. The present study examines the change experienced in the child development discipline from the past to the present. The first department of child development at the undergraduate level in Turkey was established in Hacettepe University in 1968. As of 2020, there are 86 have departments of child development in Turkey. The college admissions guide for 2019, identifies 4019 undergraduate places offered by departments of child development. Departments of child development employed 255 faculty members in 2020. Between 2003 and 2018, departments of child development graduated 6468 students. Child development graduates work in the health, education, social services, justice, and other fields. With a 52-year history and thousands of graduates to date, the departments of child development today provide services to millions of children. The ultimate goal is to ensure the necessary coverage to all children in Turkey, who account for 28 percent of the population, by increasing the number of departments of child development. The main goal in this regard is to protect and improve child health, which requires the employment of more child development specialist across the country.

Keywords: Child development, Child health, Education.

DOI: $10.24130 /$ eccd-jecs.1967202043242

Başlica Yazar:

1 T.C. Sağllk Bakanlı̆̆1, dogan.ayten@gmail.com, ORCID: 0000-0002-1163-4856

${ }^{2}$ Hacettepe Üniversitesi, Sağlık Bilimleri Fakültesi, Çocuk Gelişimi Bölümü, pinars@hacettepe.edu.tr, ORCID: 0000-0002-5466-0376 


\section{SUMMARY}

\section{Introduction}

Studies of children are conducted in many disciplines. In Turkey, universities operate child development departments that focus specifically on this field of study. The present study examines the change experienced in the child development discipline from the past to the present, with the relevance of the study including its analysis of the history of the child development field, as the sole discipline that directly tackles the subject, its investigation of the current status of the discipline, and its projections for the future.

\section{Past and Present of Child Development}

The first department of child development at the undergraduate level in Turkey was established in Hacettepe University in 1968. As of 2020, there are 207 universities in Turkey, and 86 have departments of child development - 62 in public universities and 24 in foundation universities. Of the 86 departments of child development, 62 are operated under faculties of health sciences, 14 are within health colleges, eight are within health sciences colleges and two are within open education faculties. Of the total, 38 of these departments are currently admitting students. The college admissions guide for 2019 identifies 4,019 undergraduate places offered by departments of child development -2,481 as regular day or night education programs, and 1,538 offered as open education programs.

Departments of child development employed 151 faculty members in 2015, however this number has risen to 255 in 2020. Between 2003 and 2018, departments of child development graduated 6,468 students, with graduates finding employment in the health, education, social services and justice fields, among others.

Health facilities run by the Ministry of Health employ 665 child development specialists, who are engaged in developmental surveys, evaluations, and the follow-up of children in the appropriate clinics and units of health facilities, especially in the child development clinics of hospitals. Child development specialists employed in social services work with groups in need of assistance, protection and care, and in units providing child services, family and community services, support to women, and services to the disabled and elderly, among others. Child development specialists in the field of education work in private and public schools, high schools, preschools and special education institutions. In the field of justice, child development specialists work in the family and children's courts, and in the psycho-social services units of penal institutions. In addition to the fields of health, education, and justice, child development specialists are also employed in private and municipal child development centers, and serve also in various capacities in international and civil society organizations. They are engaged in the preparation of journals, books, booklets, posters, brochures, games, toys, songs and music for children and teens; in the evaluation and utilization of these documents, materials and programs; in the preparation of television shows and children's plays; and in the examination and evaluation of the content of plays and television shows. 


\section{The Future of Child Development}

With a 52-year history and thousands of graduates to date, the departments of child development today provide services to millions of children. The ultimate goal is to ensure the necessary coverage to all children in Turkey, who account for 28 percent of the population, by increasing the number of departments of child development. The main goal in this regard is to protect and improve child health, which requires the employment of more child development specialists across the country.

\section{Conclusion}

Adopting a broad perspective when working with children or on children's issues would benefit children, and by extension, society as a whole. Children today face many problems related to war, migration, vaccine denial, chronic disease, pandemics, schooling rates, school attendance, child marriage, global warming, air pollution, and lack of access to, or the utilization of, health services, among others. All disciplines that work with children, and the child development discipline in particular, should focus on the actual or potential problems encountered by children, as focusing on a particular group while disregarding another could result in failure to produce desired results at a global level. In many disciplines, working on the global threats that concern children can affect their present and future. For all these reasons, it is of utmost importance for the future of society that specialists be employed from all disciplines connected to children, and from the discipline of child development in particular, so that the various disciplines and professions can conduct work together on children and children's issues.

In advanced researches, it may be suggested to examine the thoughts of candidates who consider to choose child development departments in universities and and to compare the content of undergraduate child development curriculum and the differences between universities. It is also recommended to analyze the current status of child development programs at postgraduate level, and to examine the professional satisfaction and problems of child development specialists. 


\section{GİRIŞ}

Çocuklar, geleceği oluşturacak bireyler olmakla birlikte çocukluk, insan gelişimi için kritik ve önemli bir dönemdir. Türkiye'nin nüfusu 83.154.997'dir (Türkiye İstatistik Kurumu [TÜİK], 2020). Türkiye nüfusunun 22.920.422'sini yani \%28'ini çocuk nüfusu oluşturmaktadır (TÜIK, 2018). Dünya nüfusunun 2050 y1lına kadar 9 milyardan fazla olacağ1 öngörülmektedir. Türkiye'nin ise 2050 y1lında nüfusunun 93.475 .575 kişi olması ve 2050 yllindan sonra ise nüfusun düşmesi beklenmektedir. Türkiye'de nüfus artış hızı düşmeye devam etmekte ve Türkiye'nin ortanca yaşının 2023'te 33,3'e, 2050'de 42,9'a ve 2075'te 47,4'e ulaşacağ1 tahmin edilmektedir (TÜİK, 2013). Bu tahminler nüfusun yaşlandığını göstermektedir. Bu veriler doğacak her çocuğun gelişimine, sağlığına ve eğitimine çok daha fazla dikkat edilmesi gerektiğini göstermektedir.

Çocuk bir toplumun geleceği anlamına gelmektedir. Dolayısıyla çocuğa yapılan yatırım geleceğe yapılan yatırımdır. Günümüzde bireylerin davranışına odaklanan ekonomistler, davranışsal ekonomi alanında çalışmalar yürütmektedir. 2019 yllında da Nobel ekonomi ödülünü alan ekonomistler 2000 yılındaki gibi bireylerin davranışlarıyla ilgili çalışmalara odaklanmışlardır. Nobel ödüllü ekonomist Heckman (2016), dezavantajlı çocuklar ve aileleri için 0-5 yaşa yapılan yatırımın en yüksek getiri oranı olan en iyi yatırım olduğunu belirtmiştir. Çünkü erken çocukluk gelişimi, bireyleri ve toplumu ekonomik, sağlık ve sosyal sonuçlarıyla doğrudan etkilemektedir (URL 1).

Çocuğun ögesi olduğu çalışmalar birçok disiplinin odak noktasıdır. Bu çalışmalar çocuğun gelişimi, sağlı̆̆ı, eğitimi, beslenmesi, aile ilişkileri gibi çok geniş bir yelpazede ele alınmaktadır. Türkiye'de doğrudan çocukların gelişimleriyle ilgilenen bilim dalı ise çocuk gelişimidir. Çocuk gelişiminin geçmişten günümüze yaşadığ1 değişim sürecini incelemek, bu çalışmanın başlica amacını oluşturmaktadır. Yapılan bu çalışmayla çocuklarla doğrudan çalışan bilim dalı olan çocuk gelişiminin geleceğe yönelik tahminleri açısından ele alınışının da önemli olduğu düşünülmektedir. Bu çalışma lisans düzeyindeki çocuk gelişimi bölümlerini; bölüm ve kontenjan sayılarını, akademik personellerini, çocuk gelişimcileri, mezun sayılarını ve mezunların görev yaptığı alanları kapsamaktadır.

\section{Çocuğun Tanımı}

Çocuk kelimesi, köken olarak Türkiye Türkçesi ağızları sözlügüne göre bebek, çocuk anlamına gelen "çoçka" kelimesinden geldiği belirtilmektedir (Türk Dil Kurumu [TDK], 2020). TDK eğitim terimleri sözlüğüne göre "Bebeklik ile ergenlik arasındaki gelişim döneminde olan insan” olarak tanımlanmaktadır. 18 yaşına kadar herkes çocuk olarak kabul edilmektedir (UNICEF, 1989). 
Çocuk, farklı kaynaklarda farklı bilim dallarında farklı kelimelerle ifade edilse de ortak olan husus, çocuğun bir gelişim ve değişim sürecinde olduğudur. Bu gelişim ve değişim sadece çocuğun kendisini değil başta ailesi olmak üzere tüm toplumu yakından ilgilendirmektedir. Türkiye'de çocukla ve çocuğun gelişimiyle ilgili çalışmaları 50 yıldan daha uzun süredir yürüten disiplin çocuk gelişimidir.

\section{Lisans Düzeyindeki Çocuk Gelişimi Bölümünün Tarihçesi}

Türkiye'de çocuk gelişiminin geçmişi, üniversitelerde aile ve çocukla ilgili bölümlerin kurulmasına dayanmaktadır. 1955 yılında, Ankara Üniversitesi, Ziraat Fakültesine bağlı Ev Ekonomisi kürsüsü; Aile İlişkileri ve Çocuk Psikolojisi gibi bilim dallanından oluşmuştur (Ankara Üniversitesi, 2015). 1968 y1lında Hacettepe Üniversitesi Sağlık Bilimleri Fakültesi Ev Ekonomisi Yüksekokulunda “Çocuk Gelişimi ve Eğitimi” adıyla lisans düzeyinde ilk bölüm kurulmuş ve bölüm 1972 yıllında rektörlüğe bağlanmıştır. Bu bölüm, kurulduğu yıldan itibaren çocuğun gelişimi, sağllğı ve eğitimi ile ilgili çalışmalar yürütmüştür. Bölümde aynı zamanda Türkiye’nin ilk "Çocuk Gelissimi ve Eğitimi Anabilim Dalı” kurulmuştur. Bölüm, 1978 yılında özel eğitim çalışmalarına başlamış ve 1982 yılında bölüm içerisinde "Özel Eğitim Anabilim Dalı” da kurulmuştur. Çocuk Gelişimi ve Eğitimi bölümü Yükseköğretim Kurulu (YÖK) kararılla 1987 yılında “Çocuk Sağllğı ve Eğitimi”, 1996 yllında yine YÖK kararıla “Çocuk Gelişimi ve Eğitimi” bölümü, 2007 yllında ise Sağlık Bilimleri Fakültesine bağlanarak "Çocuk Gelişimi” olarak yeniden yapılandırılmıştır (Hacettepe Üniversitesi, 2020). Türkiye'de çocuk gelişimi bölümlerinde şu anda Çocuk Gelişimi Anabilim Dallarının yanı sıra Özel Gereksinimli Çocukların Gelişimi Anabilim Dalları da kurulmaya başlamıştır. Lisans düzeyindeki çocuk gelişimi bölümünün tarihçesi ve zaman içerisindeki gelişimi Tablo 1'de verilmiştir.

Tablo 1. Lisans düzeyindeki çocuk gelişimi bölümünün tarihçesi

\begin{tabular}{|c|c|}
\hline Tarih & Açıklama \\
\hline 1955 & $\begin{array}{l}\text { Aile İlişkileri ve Çocuk Psikolojisi gibi bilim dallarından oluşan Ev Ekonomisi kürsüsü Ankara } \\
\text { Üniversitesi’nde kurulmuştur. }\end{array}$ \\
\hline 1968 & $\begin{array}{l}\text { 1968- } 1969 \text { ders yll döneminde Hacettepe Üniversitesi Sağlık Bilimleri Fakültesi’nin altında } \\
\text { kurulan üç yüksekokul Ev Ekonomisi Yüksekokulu, Fizyoterapi - Rehabilitasyon } \\
\text { Yüksekokulu, Hemşirelik Yüksekokulu olarak öğrenime başlamışlardır. Aynı yll Ev } \\
\text { Ekonomisi Yüksekokulu'nun içinde; Beslenme ve Diyetetik Bölü, Ev İdaresi ve Aile } \\
\text { Ekonomisi Bölümü ve Çocuk Gelişimi ve Eğitimi Bölümleri yer almışlardır. }\end{array}$ \\
\hline 1968 & $\begin{array}{l}\text { “Çocuk Gelişimi ve Eğitimi” adıyla Türkiye’de ilk bölüm Hacettepe Üniversitesi’nde } \\
\text { kurulmuştur. }\end{array}$ \\
\hline $1971-72$ & $\begin{array}{l}\text { Ev Ekonomisi Yüksekokulu'nda bulunan Çocuk Gelişimi ve Eğitimi Bölümü ile Ev İdaresi } \\
\text { ve Aile Ekonomisi Bölümleri ilk mezunlarını 1971-1972 ders yll dönemi Haziran ayında } \\
\text { vermiştir. }\end{array}$ \\
\hline 1972 & $\begin{array}{l}\text { Ev Ekonomisi Yüksekokulu dolayısıyla “Çocuk Gelişimi ve Eğitimi” bölümü de Hacettepe } \\
\text { Üniversitesi Rektörlügü̈ne bağlanmıștır. }\end{array}$ \\
\hline $1972-73$ & $\begin{array}{l}\text { Hacettepe Üniversitesi Sağllk Bilimleri Enstitüsü içinde Çocuk Gelişimi ve Eğitimi yüksek } \\
\text { lisans ve doktora programları başlamıştır. }\end{array}$ \\
\hline
\end{tabular}


1974 Lisans programlarının yapısında değişikliğe gidilerek programdaki ilk köklü değişiklik yapılmıştır.

1976 Normal gelişim gösteren ve özel gereksinimli çocuklarla çalışılabilen laboratuvar niteliğinde Gülveren semtinde anaokulu açılmıştır.

1977 Hacettepe Üniversitesi Ev Ekonomisi Yüksek Okulu Çocuk Gelişimi ve Eğitimi Bölümü mezunlarının sağlık personeli ve yardımcı sağlık personeli sayılmaları Bakanlar Kurulu kararıyla yayınlanmıştır.

1978 Hacettepe Üniversitesi Çocuk Gelişimi ve Eğitimi Bölümü özel eğitim çalışmalarına başlamıştır.

1982 Hacettepe Üniversitesi Çocuk Gelişimi ve Eğitimi bölümünde Özel Eğitim Anabilim Dalı kurulmuştur. Çocuk Gelişimi ve Eğitimi Bölümü; “Çocuk Gelişimi ve Eğitimi ABD” ve "Özel Eğitim ABD” olarak iki alanda çalışmalarını sürdürmüştür

1987 YÖK kararıyla bölümün adı “Çocuk Sağlığı ve Eğitimi” olmuștur.

1992 I. Ulusal Özel Eğitim Kongresi, Çocuk Gelişimi bölümünün düzenlediği ilk kongredir.

1995 II. Ulusal Özel Eğitim Kongresi düzenlenmiştir.

1996 YÖK kararıyla bölümün adı "Çocuk Gelişimi ve Eğitimi” olmuştur.

1997 1.Ulusal Çocuk Gelişimi ve Eğitimi Kongresi düzenlenmiştir.

2007 “Çocuk Gelişimi ve Eğitimi” bölümü “Çocuk Gelişimi” olarak Sağlık Bilimleri Fakültesi bünyesinde yeniden yapılandırılmıştır.

2009 Uluslararası Katılımlı II. Çocuk Gelişimi ve Eğitimi Kongresi düzenlenmiştir.

2011 Vakıf üniversitesinde (Okan Üniversitesi) ilk çocuk gelişimi bölümü kurularak öğrenci alımı yapılmıştır.

2012 Ahi Evran, Ankara, Hacettepe, Karabük, Kırıkkale, Kırklareli, Okan ve Üsküdar

Üniversitesi olmak üzere, devlet ve vakıf üniversitelerindeki çocuk gelişimi bölümü sayıları artmaya başlamıştır

2014 1.Ulusal Çocuk Gelişimi Öğrenci Kongresi düzenlenmiştir.

2015 Uluslararası Katılımlı III. Çocuk Gelişimi ve Eğitimi Kongresi düzenlenmiştir.

2016 Çocuk Gelişimi Lisans Eğitimi Ulusal Çekirdek Eğitim Programı hazırlanmıştır.

2018 4. Uluslararası Çocuk Gelişimi Kongresi düzenlenmiştir.

2019 Lisans düzeyinde öğrenci alımı yapan çocuk gelişimi bölümü sayısı 38’e ulaşmıştır

Kaynaklar: (Ankara Üniversitesi, 2015; Hacettepe Üniversitesi, 2020; 1969-1970 Hacettepe Üniversitesi Bülteni 1970; 1979-1980 Hacettepe Üniversitesi Bülteni, 1980; 1984/1985 Hacettepe Üniversitesi Kataloğu, 1985; Öğrenci Seçme ve Yerleştirme Merkezi [ÖSYM], 2020)

\section{Türkiye’de Bulunan Lisans Düzeyindeki Çocuk Gelişimi Bölümleri}

Türkiye'de sağlık bilimleri fakültelerine, sağlık yüksekokullarına, sağlık bilimleri yüksekokullarına, açıköğretim ve açık ve uzaktan eğitim fakültelerine bağlı lisans düzeyinde çocuk gelişimi bölümleri bulunmaktadır.

Tablo 2. Türkiye'de bulunan üniversitelerin lisans düzeyindeki çocuk gelişimi bölümlerine ilişkin frekans ve yüzde dağılımları

\begin{tabular}{ccccc}
\hline & & 2015 & & \multicolumn{2}{c}{2020} \\
\hline & $f$ & $\%$ & $f$ & $\%$ \\
Devlet & 22 & 61,1 & 62 & 72,1 \\
Vakif & 14 & 38,9 & 24 & 27,9 \\
Toplam & 36 & 100 & $86^{*}$ & 100 \\
\hline
\end{tabular}

Kaynaklar: (Doğan ve Baykoç, 2015; YÖK, 2020a).

*Dört üniversitenin ise farklı yerleşkelerinde ikişer çocuk gelişimi bölümü bulunmaktadır. 
Tablo 2'ye göre Türkiye'deki üniversitelerde lisans düzeyinde 86 çocuk gelişimi bölümü bulunmaktadır. 2015 yılında yapılan bir çalışmaya göre Türkiye'de 196 üniversite bulunmakta ve bu üniversitelerde 22'si devlet üniversitelerine, 14’ü vakıf üniversitelerine bağlı olmak üzere toplam 36 çocuk gelişimi bölümü bulunmaktadır (Doğan ve Baykoç, 2015). 2020 yllında ise Türkiye'de 207 üniversite bulunmakta ve bu üniversitelerin 62'si devlet üniversitelerine, 24'ü vakıf üniversitelerine bağlı olmak üzere toplam 86 çocuk gelişimi bölümü bulunmaktadır. Çocuk gelişimi bölümleri, hem sağlık bilimleri fakültesinin altında hem de sağlık yüksekokulları ve sağlık bilimleri yüksekokullarının altında oluştuğu gibi açıköğretim ve açık ve uzaktan eğitim fakültesi altında da yer almaktadır. Çocuk gelişimi bölümlerinin üniversitelerdeki konumları ek-1'deki tabloda gösterilmiştir.

Türkiye'de toplam 86 çocuk gelişimi bölümü bulunmaktadır. Mevcut 86 çocuk gelişimi bölümünün 62'si sağlık bilimleri fakültelerine, 14'ü sağlık yüksekokullarına, 8'i sağlık bilimleri yüksekokullarına ve 2'si açıköğretim ve açık ve uzaktan eğitim fakültelerine bağlıdır. Lisans düzeyindeki çocuk gelişimi bölümlerinin 38’i aktif olarak öğrenci kabul etmektedir.

\section{Lisans Düzeyindeki Çocuk Gelişimi Bölümlerinin Kontenjanları}

Türkiye'de üniversitelerin ve sağlık bilimleri fakültelerinin sayısının artmasıyla çocuk gelişimi bölümlerinin de sayısı artmaktadır. Çocuk gelişimi bölümlerinin sayısının artıp aktifleşmesiyle kontenjan sayıları da her yıl artış göstermiş ve göstermeye devam etmektedir.

Tablo 3. Lisans düzeyindeki çocuk gelişimi bölümü kontenjanları (tüm üniversiteler)

\begin{tabular}{cc}
\hline Y1 & Kontenjan say1s1 \\
\hline 2014 & 1279 \\
2015 & 1623 \\
2016 & 1864 \\
2017 & 2108 \\
2018 & 5602 \\
\hline 2019 & 4029 \\
\hline
\end{tabular}

Kaynak: (ÖSYM, 2020)

Tablo 3'e göre çocuk gelişimi bölümlerinde 2014 y1lı tercih k1lavuzuna göre lisans düzeyinde 1279 kontenjan bulunurken (Doğan ve Baykoç, 2015), 2015 y1lı tercih k1lavuzuna göre 1623, 2016 y1lı tercih k1lavuzuna göre 1864, 2017 y1lı tercih kılavuzuna göre 2108, 2018 y1lı tercih k1lavuzuna göre 3075’i açıöğgretim kontenjanı olmak üzere toplam 5602 ve 2019 yllı tercih kılavuzuna göre 2491 örgün ve ikinci öğretim, 1538 açıköğretim olmak üzere lisans düzeyinde çocuk gelişimi bölümlerinde toplam 4029 kontenjan bulunmaktadır. 


\section{Lisans Düzeyindeki Çocuk Gelişimi Bölümlerinin Akademik Personelleri}

"Sağlık, sağlıkla ilgili veya ilişkili programlarda eğitim ve öğretime başlanması ve sürdürülmesi için asgari koşullar” belirlenerek, Yükseköğretim Yönetim Kurulu 16/01/2019 tarihli toplantısından sonra bu koşullar YÖK tarafindan duyurulmuştur. Sağlık bilimlerine yönelik yeni program açarken asgari öğretim elemanı ile ilgili koşullar genel ilkeler belirlenmiştir. Çocuk gelişimi bölümü için asgari öğretim üyesi sayısı 3 olarak belirlenirken, öğretim üyelerinin en az 2'sinin “Çocuk Gelişimi ve Eğitimi” veya "Çocuk Sağlığı ve Eğitimi” alanlarından olması zorunlu olarak belirlenmiştir (URL, 2). Belirtilen tarihten sonra akademik personel alımlarında, bu alanlardan olma zorunluluğu dikkate alınarak çocuk gelişimi bölümlerine akademik personel alımı yapılmaktadır.

Tablo 4. Türkiye'de bulunan lisans düzeyindeki çocuk gelişimi bölümlerindeki akademik personel sayılan

\begin{tabular}{ccc}
\hline Akademik unvan & $n$ & $\%$ \\
\hline Profesör & 39 & 15,3 \\
\hline Doçent & 14 & 5,5 \\
\hline Doktor Öğretim Üyesi & 94 & 36,9 \\
Öğretim Görevlisi & 26 & 10,2 \\
\hline Araştırma Görevlisi & 82 & 32,1 \\
\hline Toplam & 255 & 100 \\
\hline
\end{tabular}

Kaynak: (YÖK, 2020b)

Tablo 4'e göre, Türkiye'de bulunan çocuk gelişimi bölümlerinde toplam 255 akademik personel bulunmaktadır. 2015 yılında yapılan bir çalışmaya göre çocuk gelişimi bölümlerindeki toplam akademik personel sayısı 151'dir (Doğan ve Baykoç, 2015). Çocuk gelişimi bölümlerinin sayısının artmasıyla akademik personel sayısı da artış göstermiştir. 2020 yılında çocuk gelişimi bölümlerinde bulunan akademik personellerin \%36,9’u doktor öğretim üyesi (doçent olmasına rağmen kadrosu doktor öğretim üyesi olanlar dahildir), \%32,1'i araştırma görevlisi, \%15,3’ü profesör, \%10,2'si öğretim görevlisi ve \%5,5’i doçenttir. Bazı üniversitelerdeki akademik personellerden doktor öğretim üyesi kadrosunda bulunanların, Üniversiteler Arası Kurul (ÜAK) kararıyla doçentlik belgesi olup doçent olmasına rağmen, üniversitelerin kendi belirlediği kriterleri sağlayamaması veya kadro açılmaması gibi nedenlerle bulundukları kadrolar doçent kadrosu değildir. Ayrıca Türkiye’de birçok bölüm akredite olmak için hazırlıklarını yapmakta olup, bazıları başvuru sürecini başlatmıştır.

\section{Çocuk Gelişimi Lisans Eğitimi Ulusal Çekirdek Eğitim Programı (ÇUÇEP)}

Çocuk gelişimi lisans eğitiminde, eğitim programının standardizasyonunu sağlamak için ulusal bir çerçeve programı oluşturulmuştur. ÇUÇEP, çocuk gelişimi bölümlerinin kendi eğitim programlarını geliştirirken temel alacakları bir program olup programın dört temel bileşeni bulunmaktadır. Bunlar; i) Çocuk gelişimi lisans eğitiminin amacı ve çocuk gelişimi lisans programı ulusal yeterlilikleri, ii) Çocuk gelişimi temel kavram, kuram ve yaklaşımları, iii) Çocuk gelişimi 
mesleği süreci, iv) Çocuk gelişimi uygulamaları ile ilgili beceriler listesinden oluşmaktadır. Bu program Türkiye'de çocuk gelişimi lisans eğitimi programlarının oluşturulması veya iyileştirilmesinde başvurulabilecek temel bir çerçeve programdır (URL 3). Bu programla lisans çocuk gelişimi programlarının eğitim içerikleri iyileştirilirken, nitelikli ve yüksek donanımlı çocuk gelişimciler yetiştirilmesi hedeflenmektedir.

\section{Lisans Düzeyindeki Çocuk Gelişimi Bölümü Mezunları}

Lisans düzeyindeki çocuk gelişimi bölümleri ve mezunları, bölümün kuruluşundan itibaren çocukların yüksek yararı doğrultusunda çalışmalarını yürütmüştür. Geçmişte bölüm ve mezun sayısı az olduğu için daha az tanınırken, günümüzde bölüm ve mezun sayısının artmasıyla tanınırlığı da oldukça artmıştır.

Hacettepe Üniversitesi kayıtlarına göre 1968 ile 2008 yıllanı arasında çocuk gelişimi mezun sayısı 2584'tür (Hacettepe Üniversitesi, 2020). Sağllk Bakanlığ1 (2014) ve Yükseköğretim Bilgi Yönetim Sistemi verilerine (YÖK, 2020a) göre 2003-2018 y1lları arasında lisans düzeyindeki çocuk gelişimi mezun say1s1 6468'dir.

Tablo 5. Lisans düzeyindeki çocuk gelişimi bölümü mezun sayıları

\begin{tabular}{|cc}
\hline Y1l & Mezun say1s1 \\
\hline $2003-2004$ & 456 \\
\hline $2004-2005$ & 404 \\
\hline $2005-2006$ & 288 \\
\hline $2006-2007$ & 294 \\
\hline $2007-2008$ & 277 \\
\hline $2008-2009$ & 288 \\
\hline $2009-2010$ & 309 \\
\hline $2010-2011$ & 307 \\
\hline $2011-2012$ & 323 \\
\hline $2012-2013$ & 151 \\
\hline $2013-2014$ & 203 \\
\hline $2014-2015$ & 252 \\
\hline $2015-2016$ & 526 \\
\hline $2016-2017$ & 964 \\
\hline $2017-2018$ & 1426 \\
\hline Toplam & 6468 \\
\hline
\end{tabular}

Kaynaklar: (Sağlık Bakanlı̆̆1, 2014; YÖK, 2020a)

Lisans düzeyindeki çocuk bölümlerinden mezun olmuş veya olacak çocuk gelişimcilerin istihdamı, sadece çocuk gelişimciler için değil sağlıklı toplumun temeli olan çocukların gelişimi ve sağlığı için de oldukça önemlidir. Çocukların gelişimi, sağllğı ve eğitimi konularında titizlikle çalışmalar yürüten çocuk gelişimi bölümleri mezunları sağlık, sosyal hizmet, eğitim, adalet ve diğer sektörlerde görev yapmaktadırlar. 


\section{Çocuk Gelişimcinin Sağlık Alanındaki Yeri}

Resmi Gazete'de (22.5.2014/29007) yayımlanan “Sağlık Meslek Mensupları ile Sağl1k Hizmetlerinde Çalışan Diğer Meslek Mensuplarının İş ve Görev Tanımlarına Dair Yönetmelik”e göre Çocuk Gelişimcinin

“a) Çocukların zihinsel, dil, motor, öz bakım, sosyal ve duygusal gelişimlerini değerlendirerek çocuğun ihtiyaçlarına yönelik gelişim destek programlarını hazırlar ve uygular. b) Sağlık kurumlarında çocuğun uyum ve gelişimine uygun ortamın hazırlanmasında görev alır. c) Riskli bebek ve çocuk izlemlerinde ilgili uzman gözetiminde görev alır ve gelişimi destekleyici çalışmaları yürütür. ç) Çocuk gelişimi ile ilgili materyallerin tasarımını planlar ve yapar. d) Aileye çocuğun gelişimine yönelik eğitim verir.” şeklinde iş ve görev tanımı yapılmıştır.

Aralık 2019 verilerine göre 583 çocuk gelişimci Sağlık Bakanlığına bağlı sağlık tesislerinde, 60’1 üniversite, 7'si özel hastanelerde olmak üzere toplam 650 çocuk gelişimci aktif olarak görev yapmaktadır. 2020 yılında açıklanan KPSS 2019/7 sonuçlarına göre 15 çocuk gelişimci daha Sağlık Bakanlığına yerleştirilmiştir. Bu durumda Sağlık Bakanlığına bağlı olarak aktif çalışan çocuk gelişimci sayısı 665’e ulaşmıştır. Bu sayı her geçen gün artmaya devam etmektedir.

Çocuk gelişimciler sağlık tesislerinde Türkiye Kamu Hastaneleri Genel Müdürlügüne (TKHGM) bağlı hastanelerde, üniversite hastanelerinde ve özel hastanelerde görev yapmaktadırlar. Çocuk gelişimciler hastanelerin çocuk gelişimi polikliniği başta olmak üzere gelişimsel pediatri, çocuk psikiyatri, çocuk nöroloji gibi ilgili poliklinik ve birimlerinde çocukların gelişimsel tarama, gelişimsel değerlendirme ve takiplerini, ilgili değerlendirme ve tarama araçlarını kullanarak ve bütüncül bir şekilde çocuğu gözlemleyerek, yapmaktadırlar. Çocuk gelişimciler çocuk gelişimi polikliniklerinin yanı sıra, hastanelerde çocukların bulunduğu servislerde, oyun odalarında görev yapmaktadır. Hastanelerde görev yapan çocuk gelişimciler bu görevlerinin yanı sıra sağlık kurullarında Çocuklar için Özel Gereksinim Raporu (ÇÖZGER) düzenlenmesinde rol almaktadırlar. TKHGM dışında Türkiye Halk Sağlı̆̆ı Genel Müdürlüğünde (THSGM) ve müdürlüğe bağlı birim ve merkezlerde de görev yapmaktadırlar. Halk sağlığı kurumlarına bağlı toplum sağlığı merkezlerinde (TSM), merkeze bağlı sağlıklı hayat merkezlerinde (SHM) görev yaparak çocuklar ve aileleriyle çalışmaktadırlar. Bunun yanı sıra TKHGM veya THSGM'ye bağlı çalışan çocuk gelişimciler hastanelerde bulunan çocuk izlem merkezlerinde (ÇİM) Sağlık Bakanlığı tarafından verilen eğitimi tamamladıktan sonra adli görüşmeci olarak görev yapmaktadır. Üniversite hastanelerinde de çocukla ilgili polikliniklerde ve çocuk gelişimi birimlerinde görev yapmaktadır. Ayrıca çocuk gelişimciler, üniversitelere bağlı 
Çocuk Koruma, Uygulama ve Araştırma Merkezleri (RG, 19.03.2006/26113) gibi hastane temelli çocuk koruma merkezlerinde görev yapabilmektedirler.

Bağımlılık danışma, anındırma ve rehabilitasyon merkezlerinde göre yapan çocuk gelişimciler ise psiko-sosyal destek ekibinde, 18 yaş altındaki hastaların gelişim dönemlerine uygun etkinlikler yürüterek, çocuğa ve ailesine destek olmaktadır (RG, 10.03.2019/30710). Her çocuk gelişimci, kendi bulunduğu merkezde çocukların sağlığının korunması ve geliştirilmesi için çocukların üstün yararı doğrultusunda çalışmalarını yürütmektedir.

\section{Sağhlk Bilimleri Lisansiyeri Olarak Çocuk Gelişimci}

Türkiye'de çocuk gelişimcilerin sağlık bilimleri lisansiyeri unvanını kullanmalarıyla ilgili geçmişten günümüze çeşitli kararlar alınmıştır. Bu kararlar; 30 Kasım 1977, 23 Şubat 2007, 16 Nisan 2008, 18 Şubat 2009, 10 Şubat 2010, 26 Ocak 2011, 02 Mart 2011, 03 Mart 2014, 18 Ekim 2017 ve 17 Ocak 2018 tarihlerinde alınan kararlardan oluşmaktadır.

Tablo 6. Sağlık bilimleri lisansiyeri unvanı

\begin{tabular}{|c|c|}
\hline Karar tarihi & Aç1klama \\
\hline 30.11 .1977 & $\begin{array}{l}\text { Hacettepe Üniversitesi Ev Ekonomisi Yüksekokulu Çocuk Gelişimi ve Eğitimi bölümü } \\
\text { mezunlarının, Sağlık Hizmetleri ve Yardımcı Sağlık Hizmetleri Sınıfından sayılmalar } \\
\text { Bakanlar Kurulunca kararlaştırılmıştır. }\end{array}$ \\
\hline 23.02.2007 & $\begin{array}{l}\text { Fakülte ve yüksekokul bazında (Sağlık Bilimleri, Sağlık Eğitim vd.) mezunların sağlık } \\
\text { bilimleri lisansiyeri olarak sayılmalarına karar verilmiștir. }\end{array}$ \\
\hline 16.04 .2008 & $\begin{array}{l}\text { Hacettepe Üniversitesi Ev Ekonomisi Yüksekokulu Çocuk Gelişimi ve Eğitimi bölümü } \\
\text { mezunlarının sağlık bilimleri lisansiyeri sayıldığına karar verilmiştir. }\end{array}$ \\
\hline 18.02.2009 & $\begin{array}{l}\text { Selçuk Üniversitesi Mesleki Eğitim Fakültesi Çocuk Gelişimi ve Eğitimi Öğretmenliğ } \\
\text { ile Hacettepe Üniversitesi Sağlık Bilimleri Fakültesi Çocuk Gelişimi bölümünün denk } \\
\text { olduğuna ve Gazi Üniversitesi Mesleki Eğitim Fakültesi Çocuk Gelişimi ve Oku } \\
\text { Öncesi Eğitimi mezunlarının sağlık bilimleri lisansiyeri kapsamında sayllı̆̆ına karar } \\
\text { verilmiştir. }\end{array}$ \\
\hline 10.02 .2010 & $\begin{array}{l}\text { Gazi Üniversitesi Mesleki Eğitim Fakültesi Çocuk Gelişimi ve Eğitimi Öğretmenliğ } \\
\text { bölümü mezunları sağllk bilimleri lisansiyeri olarak kabul edilmiştir. }\end{array}$ \\
\hline 26.01.2011 & $\begin{array}{l}\text { Ĕ̆itim Fakültesi “Çocuk Gelişimi ve Eğitimi Öğretmenliği” mezunlarının da Mesleki } \\
\text { Eğitim Fakültesi “Çocuk Gelişimi ve Eğitimi Öğretmenliği”" mezunları gibi sağlık } \\
\text { bilimleri lisansiyeri olarak kabul edilmiştir. }\end{array}$ \\
\hline 02.03 .2011 & 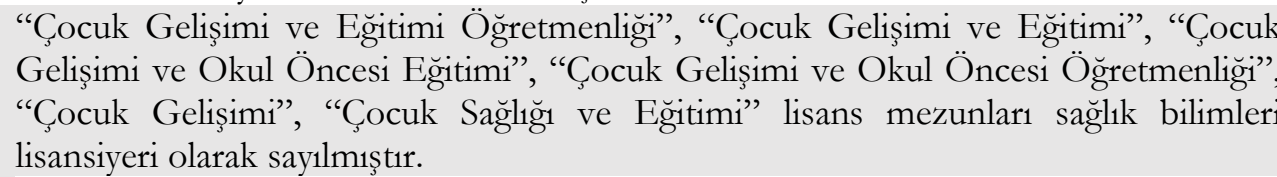 \\
\hline 03.03 .2014 & 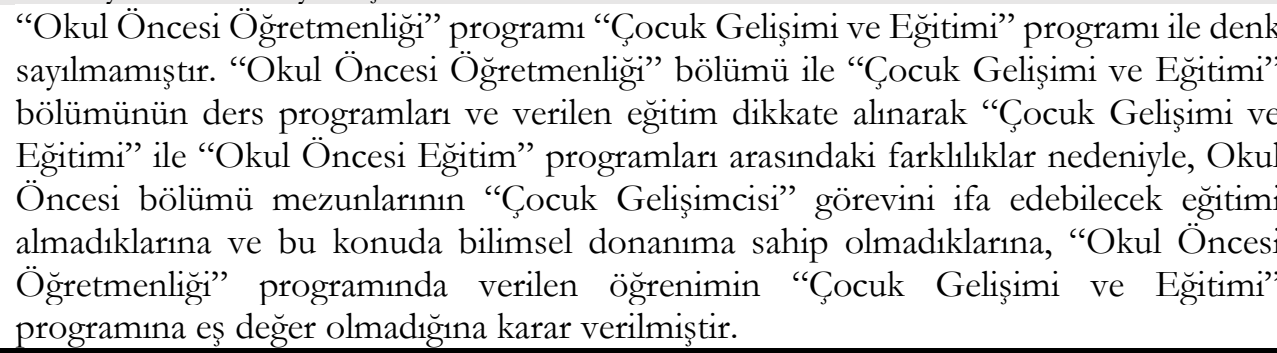 \\
\hline
\end{tabular}


18.10.2017 Sağlık Bilimleri unvanının kullanılması ve Sağlık Hizmetleri Sınıfi'nda yer alınmasıyla ilgili 23/02/2007 tarihli fakülte bazlı alınan kararın iptal edilmesine ve değerlendirmenin fakülte bazlı değil program bazlı yapılmasına karar verilmiştir. Söz konusu kararda Çocuk Gelişimi bölümü bulunmamaktadır.

17.01.2018 16/04/2008, 18/02/2009, 10/02/2010 ve 02/03/2011 tarihli kararlar iptal edilmiştir. Sağlık bilimleri lisansiyeri unvanını sadece "Çocuk Gelişimi” ile "Çocuk Sağlığı ve Gelişimi” mezunlarının kullanabileceklerine, bu iki bölümün programlarının birbirine eşdeğer olduğuna karar verilmiştir. Ayrıca "Çocuk Gelişimi ve Ev Yönetimi”, "Çocuk Gelişimi ve Okul Öncesi Eğitimi”, "Çocuk Gelişimi ve Okul Öncesi Öğretmenliği”, "Çocuk Gelişimi ve Aile Ekonomisi Yaygın Eğitim", "Çocuk Gelişimi ve Ev Ekonomisi", "Çocuk Gelişimi ve Ev Yönetimi Eğitimi”, "Çocuk Gelişimi ve Eğitimi Öğretmenliği”, "Çocuk Sağllğı ve Eğitimi” programları mezunlarının yeterliliklerinin farklı olduğuna ve sağılı bilimleri lisansiyeri unvanını kullanmalarının uygun olmadığına karar verilmiștir.

Kaynaklar: (RG, 30.11.1977/16125; Sinop Üniversitesi, 2017; URL 4)

\section{Çocuk Gelişimcinin Sosyal Hizmet Alanındaki Yeri}

Çocuk gelişimciler yardıma, korunmaya ve bakıma ihtiyacı olan gruplarla çalışmaktadır (Cesur ve Köksal Akyol, 2018). Bu alanda görev yapan çocuk gelişimciler çocuk hizmetleri, aile ve toplum hizmetleri, kadın statüsü ve engelli ve yaşlı hizmetlerine bağlı birimler başta olmak üzere ilgili diğer birimlerde görev yapmaktadır. Sosyal Hizmet Merkezleri Yönetmeliğine (RG, 09.02.2013/28554) göre çocuk gelişimci aşağıdaki görevleri ifa etmektedir.

\footnotetext{
“a) Merkeze yapılacak başvuru, ihbar ve alan taramaları veya herhangi bir şekilde tespit edilen çocukların; gelişim düzeylerini belirlemek, gelişimlerini izlemek, sorunların çözümüne yönelik olarak bu çocukların danışmanlık hizmetlerini yürütmek. b) Gelişimlerinde davranış bozukluğu belirlediği çocukları kesin tanı, tedavi ve erken eğitim amacıyla uygun kurum veya kuruluşlara yönlendirmek, sonucunu izlemek ve ilgili kuruluşlardaki uzmanlarla işbirliği içinde merkez bünyesinde verilebilecek destek hizmetlerini organize etmek. c) Mesleki test, teknik ve yöntemlerini kullanarak, çocukların gelişimlerini değerlendirmek, gelişimleri yaşlarına uygun olmayan çocuklar için bireysel destekleyici eğitim programları hazırlayarak uygulama sürecinde ailelere danışmanlık yapmak ve uygulama sonuçlarını takip etmek.".
}

Bu tanımına rağmen sosyal hizmet alanında görev yapan farklı meslek elemanlarından oluşan (çocuk gelişimi, psikoloji, sosyal hizmet, sosyoloji vd.) çalışanların, sosyal çalışma görevlisi kapsamında aynı çatı altında değerlendirilip benzer işleri yapması problemlere sebep olabilmektedir. Sosyal çalışma görevlisi çatısı altındaki tüm meslek elemanlarından aynı işin beklenmesi yerine, beklenen işleri sosyal çalışma görevlilerinden kimlerin yapacağının belirlenmesi meslek elemanlarının daha verimli çalışmasını sağlayabilir. 


\section{Çocuk Gelişimcinin Eğitim Alanındaki Yeri}

Lisans çocuk gelişimi mezunlanı ilk mezunlanını verdiği andan itibaren eğitim alanında aktif görev almıştır. Lisans mezunu çocuk gelişimciler eğitim alanında özel ve resmi okullarda, okul öncesi kurumlarında, kreş ve gündüz bakımevlerinde, özel eğitim kurumlarında, özel eğitim anaokulu ve anasınıflarında, çocuk bakımevlerinde, liselerde, rehberlik ve araştırma merkezlerinde aktif görev almaktadırlar. Bunun yanı sıra sosyal çalışma görevlisi olarak da il müdürlüklerinde çalışabilmektedirler (RG, 30.04.2015/29342).

Özel kreş ve gündüz bakımevleri ile ilgili yönetmeliğe göre (RG, 30.04.2015/29342) kurum müdürü, müdür yardımcıs1, grup sorumlusu ve branş elemanı olarak görev yapmaktadır. Ayrıca çocuk gelişimciler, kuruluşları denetleme ve değerlendirme komisyonunda yer almaktadır. Bunun yanı sıra özel eğitim anaokulu ve anasınıflarında (MEB, 2019), kamu kurum ve kuruluşlarındaki çocuk bakımevlerinde (RG, 08.12.1987/19658) de görev yapmaktadır. Liselerde ise pedagojik formasyon aldıktan sonra öğretmen olarak çalışabilmektedirler.

Milli Eğitim Bakanlığ1 Rehberlik Hizmetleri Yönetmeliği’ne göre (RG, 10.11.2017/30236) rehberlik ve araştırma merkezlerinde görevlendirilebilmektedirler. Çocuk gelişimciler rehberlik ve araştırma merkezlerindeki çocukların gelişimlerinin izlenmesinde ve gelişimsel sorunlarının çözümü için önlem alınmasında görev almaktadır.

Milli Eğitim Bakanlığ1 Özel Eğitim Kurumları Yönetmeliği’ne göre (RG, 18.05.2012/282296) özel eğitim kurumlarında görev yapan çocuk gelişimcilerin görevleri aşağıda sıralanmıştır:

“a) Bireyselleştirilmiş eğitim programının hazırlanmasında BEP geliştirme birimi ile işbirliği yapmak, b) BEP’te alanıyla ilgili uygulama ve değerlendirme yapmak, c) engelli bireylerin eğitim performanslarını ve yetersizlik türünü dikkate alarak eğitimleri sırasında kullanılmak üzere alanıyla ilgili gerekli materyalleri hazırlamak, ç) engelli bireyleri fizikî, zihinsel ve sosyal gelişim bakımından incelemek ve yaş düzeylerine uygun gelişimlerini değerlendirmek, d) engelli bireylere destek eğitim hizmeti sağlamak ve eğitim performansları doğrultusunda engelli bireylerin başka bir okul veya kuruma yönlendirilmesinde BEP geliştirme birimiyle iş birliği yapmak, e) engelli bireylerin gelişim ve eğitimini izlemek, beklenen gelişimi gösteremeyenler için ilgili meslek elemanlarıyla iş birliği yapmak, alanıyla ilgili konularda ailelere ve öğretmenlere rehberlik etmek, f) Kuruma devam eden engelli bireylere diğer kurum veya kuruluşlarda hizmet veren uzman ve öğretmenlerle eşgüdümlü çalışmak, g) Kurumdaki diğer meslek elemanlarıyla ekip çalışması yapmak ve görevlerine ilişkin kayıtları usulüne uygun şekilde tutmak, ğ) Kurumdaki aile eğitimi ve danışmanlığı çalışmalarına katılmak, sınıfındaki bireylerin ailelerine yönelik aile eğitim çalışmalarını psikolog veya rehber öğretmenle birlikte planlamak ve yürütmek," (RG, 18.05.2012/282296). 
Özel Eğitim Hizmetleri Yönetmeliği’ne göre (RG, 07.07.2018/30471) özel eğitim kurumlarında ve erken çocukluk dönemindeki çocukların eğitim hizmetlerinde çocuk gelişimi ve eğitimcileri görev almaktadır. Ayrıca özel özel eğitim ve rehabilitasyon merkezlerinde tüm özel gereksinimli çocukların bilişsel, dil, sosyal-duygusal, ince-kaba motor gelişim ve özbakım alanlarını değerlendirmeye, desteklemeye ve geliştirmeye yönelik çalışmalar ve erken çocukluk özel eğitimi ve özel eğitim alan çocuklarla çalışmalar yürütmektedir.

Milli Eğitim Bakanlı̆̆1 Ders Kitapları ve Eğitim Araçları Yönetmeliği’ne göre (RG 14.10.2015/29502) çocuk gelişimciler ders kitaplarının hazırlanmasında görev alabilmektedirler.

\section{Çocuk Gelişimcinin Adalet Alanındaki Yeri}

Çocuk Gelişimciler adalet alanında; aile ve çocuk mahkemeleri ile cumhuriyet savcllıklarının işleyişine göre sosyal çalışma görevlisi olarak görev yapabilmektedir (UNICEF, 2013). Çocuk Koruma Kanunu'na göre sosyal çalışma görevlisi; çocuk gelişimi, psikoloji, sosyal hizmet, psikolojik danışmanlık ve rehberlik, öğretmenlik, aile ve tüketici bilimleri ve sosyoloji bölümlerinden mezun olanları ifade etmektedir. Adalet Bakanlığının ilgili mahkemelerinde görev yapan sosyal çalışma görevlileri; “a)Mahkeme tarafindan istenen konularla ilgili incelemeler yapıp sonucu mahkemeye bildirir. b) Mahkeme tarafından talep edildiği takdirde duruşmada bulunup ilgili talep doğrultusunda görüş bildirir. c) Mahkeme tarafindan verilen diğer işleri yapar.” (UNICEF, 2013). Sosyal çalışma görevlileri boşanma, velayet, evlat edinme ve kişisel ilişki kurma gibi konuları içeren davalarda görev alarak sosyal inceleme raporu hazırlamaktadır (Buz, Düzyurt ve Sağlam, 2015).

“Gözlem ve Sinıflandırma Merkezleri Yönetmeliği’”ne göre (RG, 17.06.2005/25848) çocuk gelişimciler gözlem ve sınıflandırma merkezlerinde; inceleme, araştırma, değerlendirme, izlem ve sinıflandırma konularında görev yapmaktadırlar.

29 Mart 2020 tarihinde yayımlanan "Ceza İnfaz Kurumlarının Yönetimi ile Ceza ve Güvenlik Tedbirlerinin İnfazı Hakkında Yönetmelik”e göre ceza infaz kurumları psiko-sosyal yardım servisinde çocuk gelişimi uzmanının görev yaptı̆̆ı ifade edilmiştir. Bu servis;

\footnotetext{
“Personel ve hükümlülerin ruh ve beden sağlığı ve bütünlüğüne ilişkin koruyucu, geliştirici programları araştıran, uygulayan ve gerektiğinde tedavi sürecine katılarak psikolojik destek ve müdahalede bulunan, ayrıca hükümlülerin bireysel özelliklerini, yaşam koşullarını ve suç işleme nedenlerini belirleyerek bireysel gelişimlerine yardımcı olan, kurum yaşamına uyumlarını ve toplumsal yaşamla uyumlaşmalarını sağlayan ve bireyin yeniden suç işlemesini engelleyecek önlemleri alan ve bu amaçla gerektiğinde kurum üst amirinin bilgisi dahilinde, aileler ve sosyal çevreyle görüşme yapan servistir.” (RG, 29.03.2020/ 31083).
} 


\section{Çocuk Gelişimcinin Diğer Alanlardaki Yeri}

Çocuk gelişimciler sağlık, sosyal hizmet, eğitim ve adalet alanında çalışabildiği gibi belediyeler, belediyelere bağlı merkezler, sivil toplum kuruluşları ve özel çocuk gelişimi merkezlerinde de görev yapabilmektedir.

Çocuk gelişimciler çeşitli belediyelerde ve belediyelere bağlı merkezlerde; kadın sığınma evlerinde, kreşlerde çocukların bilişsel, dil, motor, sosyal ve duygusal gelişimlerini değerlendirme, sosyokültürel seviyelerine destek olma, sosyal destek çalışmaları yürütme, çocuk ve ergenlere yönelik projeler geliştirme, risk grubunda yer alan çocukları belirleme, gerekli durumlarda risk grubundaki çocuk ve ergenleri ilgili merkezlere yönlendirme konularında çalışmalar yürütmektedir.

Çocuk gelişimciler çocuk gelişimi merkezi kurarak, merkezlerde gelişimsel değerlendirme, destek ve takip, çocuk odaklı aile danışmanlığı, risk grubunda bulunan ve erken müdahale kapsamına alınması gereken çocuklara erken müdahale uygulamaları, özel gereksinimli çocuklarla özel eğitim çalışmaları yürütmektedir.

Bunun yanı sıra çocuk gelişimciler uluslararası kuruluşlarda ve sivil toplum kuruluşlarında çeşitli pozisyonlarda görev yapmaktadır. Çocuk ve gençlere yönelik dergi, kitap, kitapçık, afiş, broşür, oyun, oyuncak, şarkı ve müzik hazırlanmasında, hazırlanan bu doküman, materyal ve programların değerlendirilmesinde ve uygulamasında; çocuklara yönelik televizyon programı ve çocuk tiyatroları hazırlanmasında, hazırlanan tiyatro metinlerinin ve program içeriklerinin incelenip değerlendirilmesinde görev almaktadır.

\section{SONUÇ ve ÖNERÍLER}

Toplumun geleceği olan çocuğun tek bir disiplinin çalş̧malarılyla gelişiminin sağlanması olası değildir. Çünkü gelişim bütüncüldür. Bir çocuğun bilişsel gelişiminin veya dil gelişiminin ortalama veya ortalamanın üstünde olması tek başına yeterli değildir. Çocuğun sosyal- duygusal gelişiminin de aile ile ilişkilerinin de beslenmesinin ve çevre koşullarının da gelişiminde önemli bir yeri bulunmaktadır. Bu sebeple çocuğa bütüncül yaklaşmak gerekmektedir.

Çocuk ve çocukla ilgili konularda geniş bir perspektiften bakarak çalışmalar yapmak, çocuklara dolayısıyla topluma fayda sağlayacaktır. Günümüz çocukları savaş, göç, aşı reddi, kronik hastalıklar, salgınlar, okullaşma ve okula devam, erken yaşta evlilikler, küresel ısınma, hava kirliliği, sağlık hizmetlerine erişememe veya faydalanamama gibi birçok problemle karşı karşıyadır. Başta çocuk gelişimi disiplini olmak üzere çocukla çalışabilecek tüm disiplinler, çocukların yaşadığı veya 
yaşayabileceği bu problemlere odaklanmalıdır. Belli bir gruba odaklanıp diğer grupları göz ardı etmek küresel anlamda çocukluğa fayda sağlamayabilir. Birçok disiplin için çocuğu ilgilendiren küresel tehditlerle ilgili çalışmalar yapmak, çocuğun dününü ve bugününü değil yarınını da doğrudan etkileyecektir. Tüm bu sebeplerle başta çocuk gelişimi disiplini olmak üzere çocukla çalışan disiplinlerin istihdamını artırarak, bu disiplinlerin ve mesleklerin çocuklarla çalışmasını ve çocuklarla ilgili çalışmalar yapmasını sağlamak, ülkelerin geleceği açısından büyük önem arz etmektedir.

İleri araştırmalarda; çocuk gelişimi bölümünü ve çocuk gelişimci mesleğini seçmeyi düşünen adayların düşüncelerinin, lisans düzeyindeki çocuk gelişimi ders programları içeriklerinin ve üniversiteler arasındaki farklılıkların karşılaştırılmasının, ulusal ve uluslararası akreditasyonlarının, lisansüstü düzeyde çocuk gelişimi programlarının mevcut durumunun, çocuk gelişimcilerin mesleki tatminleri ve yaşadığı sorunların incelenmesi önerilmektedir.

\section{Sinırlilıklar}

Bu çalışma Türkiye'de bulunan lisans düzeyindeki çocuk gelişimi bölümleri ile sınırlıdır. Ayrıca lisans düzeyindeki çocuk gelişimi bölümleri ve çocuk gelişimcilerle ilgili mevcut kayıtlardan elde edilen veriler (bölüm sayıları, kontenjan sayıları, akademik personel sayıları vd.) ve mevzuatlarla sinurlidir.

\section{KAYNAKÇA}

Ankara Üniversitesi (2015). Ev ekonomisi yüksekokulu tanıtım. 10 Şubat 2015 tarihinde http://www.health.ankara.edu.tr/tarihce/ adresinden erişildi.

Buz, S., Düzyurt, K., \& Sağlam, M. (2015). Aile mahkemesinde çalışan sosyal çalışma görevlilerinin sosyal inceleme raporlarına ilişkin değerlendirmeleri: Ankara adliyesi örneği. Toplum ve Sosyal Hirmet, 26(2), 7-29.

Çocuk Koruma $\quad$ Kanunu. $20 \quad$ Şubat 2020 tarihinde https://www.mevzuat.gov.tr/MevzuatMetin/1.5.5395.pdf adresinden erişildi.

Doğan, A., \& Baykoç, N. (2015). Türkiye'de bulunan üniversitelerin lisans programlarının çocuk gelişimi açısından incelenmesi. Hacettepe Üniversitesi Sağhlk Bilimleri Fakültesi Dergisi, 1(2), 425432.

Hacettepe Üniversitesi (2020). Cocuk gelişimi bölümü tarihçesi. 2 Ocak 2020 tarihinde http://www.cge.hacettepe.edu.tr/tr/menu/tarihce-17_adresinden erişildi.

Hacettepe Üniversitesi (2020). Çocuk gelişimi bölümü tarihçesi. 2 Ocak 2020 tarihinde http://www.cge.hacettepe.edu.tr/tr/menu/tarihce-17_adresinden erişildi.

Milli Eğitim Bakanlığ1 (2019). Ögretmenlik alanlar, atama ve ders okutma esaslar. 21 Şubat 2020 tarihinde

https://ttkb.meb.gov.tr/meb_iys_dosyalar/2019_11/14162856_9_cizelgeveesaslar.pdf adresinden erişildi. 
Öğrenci Seçme ve Yerleştirme Merkezi (ÖSYM) (2020). Yükesekögrretim programlar ve kontenjanlar kılavuzu. 12 Şubat 2020 tarihinde_https://www.osym.gov.tr/_adresinden erişildi.

Resmi Gazete (07.07.2018/30471). Özel eğitim bizmetleri yönetmeliği. 10 Mart 2020 tarihinde https://www.resmigazete.gov.tr/eskiler/2018/07/20180707-8.htm adresinden erişildi.

Resmi Gazete (09.02.2013/28554). Sosyal hizmet merkęleri yönetmeliği. 16 Şubat 2020 tarihinde https://resmigazete.gov.tr/eskiler/2013/02/20130209-3.htm adresinden erissildi.

Resmi Gazete (10.11.2017/30236). Rebberlik bizmetleri yönetmeliği. 20 Şubat 2020 tarihinde https://orgm.meb.gov.tr/meb_iys_dosyalar/2017_11/10113305_yeni_rehbrlk_yon.pdf adresinden erișildi.

Resmi Gazete (22.05.2014/29007). Sağhlk meslek mensuplarn ile sağhlk bizmetlerinde çallsan diğer meslek mensuplarmm işve görev tanmlarna dair jönetmelik. 10 Mart 2020 tarihinde https://www.resmigazete.gov.tr/eskiler/2014/05/20140522-14.htm_adresinden erişildi.

Resmi Gazete (29.03.2015/29310). Cocuk destek merkezleri yönetmeliği. 10 Mart 2020 tarihinde https:// resmigazete.gov.tr/eskiler/2015/03/20150329-1.htm adresinden erişildi.

Resmi Gazete (30.04.2015/29342). Özel kreş ve gündür bakemevleri ile özel çocuk kulüplerinin kurulus ve isleyis esaslar bakkenda yönetmelik. 10 Ocak 2020 tarihinde https://resmigazete.gov.tr/eskiler/2015/04/20150430-4.htm_adresinden erişildi.

Resmi Gazete (30.11.1977/16125). Hacettepe Üniversitesi Ev Ekonomisi Yülesek Okulu Cocuk Gelisimi ve Ë̆itimi bölümü mezunlarmm sağhk hizmetleri ve yardımo sağhlk hizmetleri sinffindan saynlmalar hak.kinda karar. 2 Ocak 2020 tarihinde https://www.resmigazete.gov.tr/arsiv/16125.pdf adresinden erișildi.

Resmi Gazete (17.06.2005/25848). Gözlem ve simflandirma merkezleri yönetmeliği. https://www.mevzuat.gov.tr/mevzuat?MevzuatNo=8346\&MevzuatTur=7\&MevzuatTert ip $=5$ adresinden erişildi.

Resmi Gazete (10.03.2019/30710). Bağımlllı danışma, armdırma ve rehabilitasyon merkezleri hakekında yönetmelik. https://www.resmigazete.gov.tr/eskiler/2019/03/20190310-2.htm adresinden erişildi.

Resmi Gazete (08.12.1987/19658). Kamu kurum ve kuruluslarnca açlacak çocuk bakımevleri bakekinda yönetmelik.

https://www.mevzuat.gov.tr/mevzuat?MevzuatNo=8712197\&MevzuatTur=3\&Mevzuat Tertip $=5$ adresinden erişildi.

Resmi Gazete (14.10.2015/29502). Millî Ë̆itim Bakanlĭ̆ ders kitaplar ve eğitim araçlar yönetmeliği. https://www.mevzuat.gov.tr/mevzuat?MevzuatNo=16593\&MevzuatTur=7\&MevzuatTe rtip $=5$ adresinden erişildi.

Resmi Gazete (18.05.2012/28296). Milli Eüitim Bakanlü̆ özel eğitim kurumlar yönetmeliüi. https://www.mevzuat.gov.tr/mevzuat?MevzuatNo=16154\&MevzuatTur=7\&MevzuatTe rtip $=5$ adresinden erişildi.

Resmi Gazete (19.03.2006/26113). Gaz̧i Üniversitesi çocuk koruma, uygulama ve araştırma merkez̧i yönetmeliği. $\quad 20 \quad$ Temmuz $2020 \quad$ tarihinde https://www.resmigazete.gov.tr/eskiler/2006/03/20060319-2.htm adresinden erissildi.

Sağllk Bakanlığ1 (2014). Türkiye'de sağllk eğitimi ve sağhk insan gücü durum raporu. 30 Aralık 2019 tarihinde https://sbu.saglik.gov.tr/Ekutuphane/kitaplar/insangucu.pdf adresinden erişildi.

Sinop Üniversitesi (2017). Sağhlk bilimleri lisansiyeri unvan alan lisans programlar bakkeında görüs. 2 Ocak 2020 tarihinde 
http://oldpdb.sinop.edu.tr/dosya/Personel_Daire_Baskanligi_websitesi/personel_daire_ baskanligi/formlar/SlkBlmlerLsnsyrlerUnvnAlnLsnsPrgrmlrHkkndYKnGrs.pdf adresinden erişildi.

Türk Dil Kurumu (TDK) (2020). Sözlïk. 4 Ocak 2020 tarihinde https://sozluk.gov.tr/ adresinden erişildi.

Türkiye İstatistik Kurumu (TÜIK) (2012). Türkiye'nin demografik yapısı ve geleceği. 28 Aralık 2019 tarihinde http://tuik.gov.tr/PreHaberBultenleri.do?id=13140_adresinden erişildi.

Türkiye İstatistik Kurumu (TÜİK) (2013). Nüfus projeksiyonlar, 2013-2075. 15 Şubat 2020 tarihinde http://www.tuik.gov.tr/PreHaberBultenleri.do?id=15844 adresinden erişildi.

Türkiye İstatistik Kurumu (TÜIK) (2018). Istatistiklerle çocuk. 28 Aralı 2019 tarihinde http:/ / www.tuik.gov.tr/PreHaberBultenleri.do?id=30708_adresinden erişildi.

Türkiye İstatistik Kurumu (TÜİK) (2020). Adrese dayal nüfus kaynt sistemi sonuclar. 14 Şubat 2020 tarihinde http://www.tuik.gov.tr/PreHaberBultenleri.do?id=33705 adresinden erişildi.

UNICEF (1989). Cocuk baklarna dair sözlesme. 16 Şubat 2020 tarihinde https://www.unicef.org/turkey/\%C3\%A7ocuk-haklar\%C4\%B1na-dairs\%C3\%B6zle \%C5\%9Fme_adresinden erişildi.

UNICEF (2013). Sosyal çalısma görevlileri için eğitim kitabı. 20 Şubat 2020 tarihinde http://www.unicef.org.tr/vera/app/var/files/s/o/sosyal-calisma-gorevlileri-icin-egitimkitabi.pdf adresinden erişildi.

URL 1. There's more to gain by taking a comprehensive approach to early childhood development. 5 Ocak 2020 tarihinde_https://heckmanequation.org/ adresinden erişildi.

URL 2. Sağhlk, sağhkla ilgili veya ilişkili programlarda eğitim ve ögretime bașlanmasi ve sürdürülmesi için asgari kosullar genel ilkeler. 20 Ocak 2020 tarihinde https://www.yok.gov.tr/Documents/Kurumsal/egitim_ogretim_dairesi/Yok-tarafindanAsgari-Kosullari-Belirlenen-Programlar/saglik_Programlari.pdf adresinden erişildi.

URL 3. Cocuk gelişimi lisans eğitimi ulusal cekirdek eğitim programı 2 Ocak 2020 tarihinde https://www.yok.gov.tr/Documents/Kurumsal/egitim_ogretim_dairesi/Ulusal-cekirdekegitimi-programlari/cocuk_gelisimi_cekirdek_egitim_programi.pdf adresinden erişildi.

URL 4. Kimler sağllk bilimleri lisansiyeri sayllır? 10 Mart 2014 taribli haber. 2 Ocak 2020 tarihinde https://www.memurlar.net/haber/459942/kimler-saglik-bilimleri-lisansiyeri-sayilir.html adresinden erişildi.

Yükseköğretim Kurulu (YÖK) (2020a). Yükesekögretim bilgi yönetim sistemi. 3 Ocak-12 Şubat 2020 tarihleri arasinda https://istatistik.yok.gov.tr/ adresinden erişildi.

Yükseköğretim Kurulu (YÖK) (2020b). YÖK akademik. 5 Ocak 2020 tarihinde https://akademik.yok.gov.tr/AkademikArama/_adresinden erişildi.

1969-1970 Hacettepe Üniversitesi Bülteni (1970). Ankara: Hacettepe Üniversitesi.

1979-1980 Hacettepe Üniversitesi Bülteni (1980). Ankara: Hacettepe Üniversitesi.

1984/1985 Hacettepe Üniversitesi Kataloğu (1985). Ankara: Hacettepe Üniversitesi. 


\section{EK:}

Türkiye'de Bulunan Lisans Düzeyindeki Çocuk Gelişimi Bölümleri

\begin{tabular}{|c|c|c|c|}
\hline Üniversite ad1 & Bağlı olduğu fakülte veya yüksekokul & $\begin{array}{l}\text { Açılış } \\
\text { tarihi }\end{array}$ & $\begin{array}{c}\text { Üniversite } \\
\text { türü }\end{array}$ \\
\hline Afyon Kocatepe Üniversitesi & Sandıklı Uygulamalı Bilimler Yüksekokulu & 28.02 .2018 & Devlet \\
\hline Akdeniz Üniversitesi & Kumluca Sağl1k Bilimleri Fakültesi & 29.07 .2015 & Devlet \\
\hline Aksaray Üniversitesi & Sağl1k Bilimleri Fakültesi & 10.10.2017 & Devlet \\
\hline \multicolumn{4}{|l|}{ Alanya Alaaddin Keykubat } \\
\hline Üniversitesi & Sağlık Bilimleri Fakültesi & 27.09 .2016 & Devlet \\
\hline Ankara Üniversitesi & Sağlık Bilimleri Fakültesi & 01.07 .2009 & Devlet \\
\hline Ankara Y1ldırım Beyazıt Üniversitesi & Sağlık Bilimleri Fakültesi & 21.07.2010 & Devlet \\
\hline Artvin Çoruh Üniversitesi & Sağlık Bilimleri Fakültesi & 27.08 .2015 & Devlet \\
\hline Atatürk Üniversitesi & Açıköğretim Fakültesi & 29.01 .2014 & Devlet \\
\hline Atatürk Üniversitesi & Sağlık Bilimleri Fakültesi & 20.01.2016 & Devlet \\
\hline Atılım Üniversitesi & Sağlık Bilimleri Fakültesi & 13.04.2017 & Vakıf \\
\hline Avrasya Üniversitesi & Sağlık Bilimleri Fakültesi & 15.01.2013 & Vakif \\
\hline Aydin Adnan Menderes Üniversitesi & Sağlık Bilimleri Fakültesi & 05.12 .2012 & Devlet \\
\hline Bahçeşehir Üniversitesi & Sağlık Bilimleri Fakültesi & 10.07.2013 & Vakıf \\
\hline Bandırma Onyedi Eylül Üniversitesi & Sağlık Bilimleri Fakültesi & 09.12 .2015 & Devlet \\
\hline Bartın Üniversitesi & Sağlık Bilimleri Fakültesi & 14.03.2018 & Devlet \\
\hline Batman Üniversitesi & Sağlık Yüksekokulu & 17.10.2018 & Devlet \\
\hline Beykent Üniversitesi & Sağlık Bilimleri Yüksekokulu & 15.01.2013 & Vakıf \\
\hline Bezm-İ Âlem Vakıf Üniversitesi & Sağlık Bilimleri Fakültesi & 19.01.2011 & Vakif \\
\hline Bilecik Şeyh Edebali Üniversitesi & Sağlık Bilimleri Fakültesi & 20.02 .2013 & Devlet \\
\hline Bingöl Üniversitesi & Sağlık Bilimleri Fakültesi & 08.04 .2016 & Devlet \\
\hline Biruni Üniversitesi & Sağlık Bilimleri Fakültesi & 12.03.2014 & Vakıf \\
\hline Bitlis Eren Üniversitesi & Sağlık Yüksekokulu & 18.02.2015 & Devlet \\
\hline Burdur Mehmet Akif Ersoy & & & \\
\hline Üniversitesi & Bucak Sağlik Yüksekokulu & 31.01 .2013 & Devlet \\
\hline Çankırı Karatekin Üniversitesi & Sağlık Bilimleri Fakültesi & 29.08 .2016 & Devlet \\
\hline Doğuş Üniversitesi & Sağlık Bilimleri Yüksekokulu & 29.01 .2014 & Vakıf \\
\hline Ege Üniversitesi & İzmir Ödemiş Sağlık Yüksekokulu & 12.12.2018 & Devlet \\
\hline Erzincan Binali Yıldırım Üniversitesi & Sağlık Bilimleri Fakültesi & 13.04.2017 & Devlet \\
\hline Eskişehir Osmangazi Üniversitesi & Sağlık Bilimleri Fakültesi & 27.08 .2015 & Devlet \\
\hline Giresun Üniversitesi & Görele Uygulamalı Bilimler Yüksekokulu & 15.01.2020 & Devlet \\
\hline Gümüşhane Üniversitesi & Sağlık Bilimleri Fakültesi & 14.03.2012 & Devlet \\
\hline Hacettepe Üniversitesi & Sağlık Bilimleri Fakültesi & 09.07 .2009 & Devlet \\
\hline Harran Üniversitesi & Viranşehir Sağlık Yüksekokulu & 16.08.2017 & Devlet \\
\hline Hitit Üniversitesi & Sağlık Bilimleri Fakültesi & 06.07 .2018 & Devlet \\
\hline Iğdır Üniversitesi & Sağlık Bilimleri Fakültesi & 29.01 .2020 & Devlet \\
\hline İnönü Üniversitesi & Sağlık Bilimleri Fakültesi & 27.08 .2015 & Devlet \\
\hline İstanbul Üniversitesi & Açık ve Uzaktan Eğitim Fakültesi & 2018 & Devlet \\
\hline İstanbul Arel Üniversitesi & Sağlık Bilimleri Yüksekokulu & 11.04.2012 & Vakıf \\
\hline İstanbul Aydin Üniversitesi & Sağlık Bilimleri Fakültesi & 03.01 .2013 & Vakıf \\
\hline İstanbul Bilgi Üniversitesi & Sağlık Bilimleri Fakültesi & 03.01 .2017 & Vak1f \\
\hline İstanbul Esenyurt Üniversitesi & Sağlık Bilimleri Fakültesi & 03.06 .2015 & Vak1f \\
\hline İstanbul Gedik Üniversitesi & Sağlık Bilimleri Fakültesi & 29.03 .2017 & Vakif \\
\hline İstanbul Gelişim Üniversitesi & Sağlık Bilimleri Yüksekokulu & 13.09.2012 & Vak1f \\
\hline İstanbul Kent Üniversitesi & Sağlık Bilimleri Fakültesi & 18.05.2017 & Vakif \\
\hline İstanbul Medeniyet Üniversitesi & Sağlık Bilimleri Fakültesi & 21.07.2010 & Devlet \\
\hline İstanbul Medipol Üniversitesi & Sağlık Bilimleri Fakültesi & 26.03 .2014 & Vakıf \\
\hline İstanbul Medipol Üniversitesi & Sağlık Bilimleri Yüksekokulu & 25.03 .2015 & Vakif \\
\hline İstanbul Okan Üniversitesi & Sağlık Bilimleri Fakültesi & 10.06.2010 & Vak1f \\
\hline
\end{tabular}




\begin{tabular}{|c|c|c|c|}
\hline İstanbul Rumeli Üniversitesi & Sağlık Bilimleri Yüksekokulu & 29.03 .2017 & Vakıf \\
\hline İstinye Üniversitesi & Sağllk Bilimleri Fakültesi & 23.03 .2016 & Vakif \\
\hline İzmir Bakırçay Üniversitesi & Sağlık Bilimleri Fakültesi & 25.10 .2017 & Devlet \\
\hline İzmir Ekonomi Üniversitesi & Sağlık Bilimleri Fakültesi & 03.02 .2016 & Vak1f \\
\hline İzmir Kâtip Çelebi Üniversitesi & Sağlık Bilimleri Fakültesi & 20.03 .2019 & Devlet \\
\hline Kafkas Üniversitesi & Sağlık Bilimleri Fakültesi & 27.08 .2015 & Devlet \\
\hline Kahramanmaraş İstiklal Üniversitesi & Sağlık Bilimleri Fakültesi & 10.04.2019 & Devlet \\
\hline Kapadokya Üniversitesi & Sağllk Bilimleri Yüksekokulu & 07.02 .2018 & Vakif \\
\hline Karabük Üniversitesi & Sağllk Bilimleri Fakültesi & 11.04.2012 & Devlet \\
\hline Karadeniz Teknik Üniversitesi & Sağllk Bilimleri Fakültesi & 24.11 .2010 & Devlet \\
\hline \multicolumn{4}{|l|}{ Karamanoğlu Mehmetbey } \\
\hline Üniversitesi & Sağllk Bilimleri Fakültesi & 31.05 .2017 & Devlet \\
\hline Kurıkkale Üniversitesi & Sağllk Bilimleri Fakültesi & 31.03 .2009 & Devlet \\
\hline Kırklareli Üniversitesi & Sağlık Yüksekokulu & 12.08.2009 & Devlet \\
\hline Kırşehir Ahi Evran Üniversitesi & Sağlık Bilimleri Fakültesi & 07.10 .1999 & Devlet \\
\hline Kilis 7 Aralık Üniversitesi & Yusuf Şerefoğlu Sağlık Bilimleri Fakültesi & 06.07 .2018 & Devlet \\
\hline KTO Karatay Üniversitesi & Sağlık Bilimleri Yüksekokulu & 25.11.2014 & Vakif \\
\hline Lokman Hekim Üniversitesi & Sağlık Bilimleri Fakültesi & 07.03 .2018 & Vakıf \\
\hline Mardin Artuklu Üniversitesi & Sağllk Bilimleri Fakültesi & 18.04.2019 & Devlet \\
\hline Mersin Üniversitesi & İçel Sağlık Yüksekokulu & 01.10 .2014 & Devlet \\
\hline Munzur Üniversitesi & Sağllk Bilimleri Fakültesi & 18.04.2019 & Devlet \\
\hline Necmettin Erbakan Üniversitesi & Sağlık Bilimleri Fakültesi & 25.12.2019 & Devlet \\
\hline Nevşehir Hacı Bektaş Veli & Semra ve Vefa Küçük Sağlık Bilimleri & & \\
\hline Üniversitesi & Fakültesi & 04.12.2019 & Devlet \\
\hline Niğde Ömer Halisdemir Üniversitesi & Niğde Zübeyde Hanım Sağlık Yüksekokulu & 03.11 .2011 & Devlet \\
\hline Ondokuz Mayıs Üniversitesi & Sağlık Bilimleri Fakültesi & 24.04 .2019 & Devlet \\
\hline Ordu Üniversitesi & Sağlık Bilimleri Fakültesi & 01.02 .2012 & Devlet \\
\hline Sağlık Bilimleri Üniversitesi & Gülhane Sağlık Bilimleri Fakültesi & 13.09 .2017 & Devlet \\
\hline \multirow[t]{2}{*}{ Sağlık Bilimleri Üniversitesi } & Hamidiye Sağlık Bilimleri Fakültesi & 06.01 .2016 & Devlet \\
\hline & Akşehir Kadir Yallagöz Sağlık & & \\
\hline Selçuk Üniversitesi & Yüksekokulu & 19.09 .2018 & Devlet \\
\hline Selçuk Üniversitesi & Sağlık Bilimleri Fakültesi & 17.04.2013 & Devlet \\
\hline Siirt Üniversitesi & Sağllk Yüksekokulu & 24.06 .2015 & Devlet \\
\hline Sinop Üniversitesi & Sağlık Yüksekokulu & 08.04 .2014 & Devlet \\
\hline Şırnak Üniversitesi & Sağlık Bilimleri Fakültesi & 31.07 .2019 & Devlet \\
\hline Tokat Gaziosmanpaşa Üniversitesi & Sağlık Bilimleri Fakültesi & 22.01 .2020 & Devlet \\
\hline Trakya Üniversitesi & Keşan Hakkı Yörük Sağl1k Yüksekokulu & 03.12 .2013 & Devlet \\
\hline Üsküdar Üniversitesi & Sağlık Bilimleri Fakültesi & 29.03 .2012 & Vak1f \\
\hline Van Yüzüncü Yıl Üniversitesi & Sağllk Bilimleri Fakültesi & 01.02 .2017 & Devlet \\
\hline Yalova Üniversitesi & Sağlık Bilimleri Fakültesi & 27.02.2019 & Devlet \\
\hline Yozgat Bozok Üniversitesi & Sağlık Bilimleri Fakültesi & 26.11.2017 & Devlet \\
\hline Zonguldak Bülent Ecevit Üniversitesi & Sağlık Bilimleri Fakültesi & 28.12 .2016 & Devlet \\
\hline
\end{tabular}

Kaynak: Yükseköğretim Bilgi Yönetim Sistemi (2020). https://istatistik.yok.gov.tr/ Erişim tarihi: 20.02.2020 